UDC: 330.5: 332.1

\author{
Jacek Binda ${ }^{a}$, Sylwia Niedziela ${ }^{\text {b) }}$ \\ a) Bielsko-Biała School of Finance and Law, Bielsko-Biała, Poland \\ b) Tax Administration Chamber in Katowice, Katowice, Poland \\ a) https://orcid.org/0000-0002-2016-9933,e-mail: jbinda@wsfip.edu.pl \\ b) https://orcid.org/0000-0002-7003-2580
}

\title{
The Participatory Budgets Implementation on the Example of Selected Municipalities
}

In recent years, participatory budgets are one of the most dynamically developing institutions of social participation. The implementation of the participatory budget in local government units is an endeavor to increase the degree of involvement of the inhabitants of a given community to co-decide on spending budget funds. Implementation of a participatory budget requires a well-constructed procedure, which will engage the highest possible number of residents and lead to a more rational and efficient utilisation of budget resources of local government units. We analysed the problems of the implementations of participatory budgets in the Polish communes of Jaworze, Cieszyn, Kęty and Bielsko-Biała (South of Poland) and discussed challenges, which accompanied this process. We hypothesised that the complicated and ambiguous participatory budget procedure is the reason for a low efficiency of spending funds under participatory budgets in the analysed communes. The analysis was based on the literature review of amendments to Polish legislation that define the notion of the participatory budget and lay foundations for its functioning. We compared various constituents of the procedure applied in the examined communes, used in the process of the participatory budget implementation. Research results indicated that the participatory budget model should be changed to optimise expenditure of local funds, increase local community satisfaction and accelerate the development of the commune. The results may be used to assess the effectiveness of the spending of funds under the participatory budget in other municipalities of the region.

Keywords: participatory budget, investment, local government unit, municipal budget, public participation, participatory democracy, decision-making process, decentralised district of a local authority, collective action, deliberative methods, deliberative democracy

For citation: Binda, J. \& Niedziela, S. (2021). The Participatory Budgets Implementation on the Example of Selected Municipalities. Ekonomika regiona [Economy of region], 17(1), 288-300, https://doi.org/10.17059/ekon.reg.2021-1-22

\footnotetext{
${ }^{1}$ (c) Binda J., Niedziela S. Text. 2021.
} 


\author{
Я. Бинда ${ }^{a)}$, С. Недзеля б) \\ а) Высшая школа финансов и права в Бельско-Бяла, Бельско-Бяла, Польша \\ 6) Палата налогового администрирования в Катовице, Катовице, Польша \\ a) https://orcid.org/0000-0002-2016-9933,e-mail: jbinda@wsfip.edu.pl \\ 6) https://orcid.org/0000-0002-7003-2580
}

\begin{abstract}
Партисипативне бюджетирование на примере отдельных муниципалитетов
В последние годы партисипативный бюджет стал одним из наиболее динамично развивающихся институтов общественного участия. Партисипаторное бюджетирование направлено на вовлечение жителей конкретной территории в проиессы принятия местными органами власти решений о расходовании бюджетных средств. Хорошо продуманный алгоритм партисипаторного бюджетирования должен задействовать максимально возможное количество жителей; такой подход приведет к рациональному и эффективному использованию бюджетных ресурсов местных территориальных образований. В статье анализируются проблемы партисипаторного бюджетирования в польских коммунах Явоже, Цешин, Кенты и Бельско-Бяла (юг Польши) и обсуждаются сопутствующие задачи. Была выдвинута гипотеза: низкая эффективности расходования бюджетных средств в анализируемых коммунах связана со сложностью алгоритма партисипаторного бюджетирования. В основе анализа лежит обзор литературы, касающейся поправок в польском законодательстве, определяющих понятие партисипативного бюджета и правила его функционирования. В статье сравниваются различные составляющие алгоритмов, применяемых в проиессе партисипаторного бюджетирования в исследуемых коммунах. Результаты исследования показали, что для оптимизации расходов бюджетных средств, повышения удовлетворенности местного населения и развития коммун необходимо трансформировать модель партисипаторного бюджетирования. Данные результать могут быть использованы для оценки эффективности расходования средств в рамках партисипативного бюджета в других муниципалитетах региона.

Ключевые слова: партисипативный бюджет, инвестиции, единица местного самоуправления, муниципальный бюджет, общественное участие, демократия на основе участия, процесс принятия решений, децентрализация местной власти, коллективные действия, совещательные методы, совещательная демократия
\end{abstract}

Для цитирования: Бинда Я., Недзеля С. Партисипативне бюджетирование на примере отдельных муниципалитетов // Экономика региона. 2021. Т. 17, вып. 1. С. 288-300. https://doi.org/10.17059/ekon.reg.2021-1-22

\section{Introduction}

The democratic system of a state requires citizen participation in the decision-making process and respect for the rights of others. One of the tools enabling this process is a participatory budget (sometimes called a civic budget) [1, 2], which is regarded as the highest level of cooperation between residents and local authorities due to the direct, active involvement of citizens in the running of the community. It can be defined as a process of democratic deliberation and decision-making, in which ordinary people decide how to allocate part of a municipal or public budget. It also allows citizens to identify, discuss, promote and prioritise public spending projects, as they have a significant influence on real decisions about how to spend money $[3,4]$. The adoption of the participatory budget, which is neither a concept with formal and legal definition nor an obligation for local government authorities, is an increasingly common practise $[5,6]$. In the years 2005-2012, experiments with participatory budgeting in Europe increased from 55 to over 1300 , involving more than 8 million European Union citizens. Moreover, both national authorities and supranational administrations, including the European Union (EU), incentivise the use of participatory budgeting among governments and sub-national authorities. This action is evident in the number of loans and subsidies granted by the World Bank since 2012 (over US $\$ 280$ million) to support participatory budgeting projects in at least 15 countries ${ }^{1}$. Therefore, it is undeniable that participatory budgets help shape local development according to expectations of residents [7, 8] and build their trust in local authorities. In this way, local decision-makers may get recognition and approval for the actions they undertake for the sake of local communities $[9,10]$. The framework of participatory budgeting varies across the globe in procedures and objectives, depending on whether it is considered at the municipal, regional or provincial level [11]. Regardless of the above differences, participatory budget has become a central topic of discussion for local government units involved in democracy and local development.

The first Polish town that decided to benefit from the idea of a participatory budget was Sopot. The increase in social responsibility of res-

\footnotetext{
${ }^{1}$ Sgueo, G. (2016). Participatory budgeting. An innovative approach. Europarl.europa.eu. Retrieved from: http://www.europarl.europa.eu/RegData/etudes/BRIE/2016/573894/EPRS_ BRI\%282016 \%29573894_EN.pdf. (Date of access: 13.02.2020).
} 
Table 1

European participatory budget models

\begin{tabular}{|c|c|c|c|c|c|}
\hline & $\begin{array}{c}\begin{array}{c}\text { Porto Alegre } \\
\text { model adapted for } \\
\text { Europe }\end{array} \\
\end{array}$ & $\begin{array}{c}\text { Proximity } \\
\text { participation }\end{array}$ & $\begin{array}{l}\text { Consultation on } \\
\text { public finance }\end{array}$ & $\begin{array}{l}\text { Community participa- } \\
\text { tory budgeting }\end{array}$ & $\begin{array}{c}\text { Multi-stakeholder } \\
\text { participation }\end{array}$ \\
\hline $\begin{array}{l}\text { Decision- mak- } \\
\text { ing body }\end{array}$ & $\begin{array}{l}\text { composed of cit- } \\
\text { izens' elected } \\
\text { delegates }\end{array}$ & $\begin{array}{l}\text { local } \\
\text { administration }\end{array}$ & $\begin{array}{l}\text { local } \\
\text { administration }\end{array}$ & $\begin{array}{l}\text { composed of representa- } \\
\text { tives of local government } \\
\text { (LG), non-governmental } \\
\text { organisations (NGOs), } \\
\text { state organisations }\end{array}$ & $\begin{array}{l}\text { composed of rep- } \\
\text { resentatives of LG, } \\
\text { NGOs, state or- } \\
\text { ganisations, private } \\
\text { sector }\end{array}$ \\
\hline \multirow{8}{*}{ Participation } & \multicolumn{5}{|c|}{ Participants' selection methods } \\
\hline & self-selection & self-selection & \begin{tabular}{|l|} 
random \\
selection
\end{tabular} & targeted selection & targeted selection \\
\hline & \multicolumn{5}{|c|}{ Scope of participation } \\
\hline & $\begin{array}{l}\text { single active } \\
\text { citizens }\end{array}$ & $\begin{array}{l}\text { single active } \\
\text { citizens }\end{array}$ & $\begin{array}{l}\text { "ordinary" } \\
\text { citizens }\end{array}$ & organised citizens & $\begin{array}{l}\text { organised citizens } \\
\text { together with pri- } \\
\text { vate enterprise } \\
\end{array}$ \\
\hline & \multicolumn{5}{|c|}{ Participation mechanisms } \\
\hline & open access & open access & open access & open access & closed access \\
\hline & \multicolumn{5}{|c|}{ Representation level } \\
\hline & $\begin{array}{l}\text { neighbourhood } \\
\text { and city level }\end{array}$ & $\begin{array}{l}\text { neighbourhood } \\
\text { and city level }\end{array}$ & city level & $\begin{array}{l}\text { neighbourhood and city } \\
\text { level }\end{array}$ & city level \\
\hline \multirow{6}{*}{ Deliberation } & \multicolumn{5}{|c|}{ Focus of discussion - level of investment } \\
\hline & public & $\begin{array}{l}\text { micro local } \\
\text { public or broad } \\
\text { guidelines of } \\
\text { city policy }\end{array}$ & $\begin{array}{l}\text { overall budget or } \\
\text { offer of services }\end{array}$ & community projects & $\begin{array}{l}\text { projects financed } \\
\text { by public/ private } \\
\text { partnerships }\end{array}$ \\
\hline & \multicolumn{5}{|c|}{ Modes of communication - the way preferences are expressed } \\
\hline & developer & donor & donor & developer, donor & developer, donor \\
\hline & \multicolumn{5}{|c|}{ Formality of the process - way projects are ranked (investments) } \\
\hline & $\begin{array}{l}\text { ranked (formal } \\
\text { rules) }\end{array}$ & $\begin{array}{l}\text { not ranked (in- } \\
\text { formal rules) }\end{array}$ & \begin{tabular}{|l|} 
not ranked \\
(rather informal \\
rules)
\end{tabular} & ranked (formal rules) & $\begin{array}{l}\text { ranked (formal } \\
\text { rules) }\end{array}$ \\
\hline Empowerment & $\begin{array}{l}\text { decision-making } \\
\text { power }\end{array}$ & consultation & consultation & $\begin{array}{l}\text { co-governing } \\
\text { partnership }\end{array}$ & $\begin{array}{l}\text { co-governing } \\
\text { partnership }\end{array}$ \\
\hline $\begin{array}{l}\text { Control and } \\
\text { monitoring }\end{array}$ & elected delegates & $\begin{array}{l}\text { local } \\
\text { administration }\end{array}$ & $\begin{array}{l}\text { local } \\
\text { administration }\end{array}$ & $\begin{array}{l}\text { local administration and } \\
\text { donors }\end{array}$ & $\begin{array}{l}\text { local administra- } \\
\text { tion and donors }\end{array}$ \\
\hline
\end{tabular}

Source: Based on [14].

idents, who were able to influence the development of their immediate environment, was considered one of the success factors. Following the example of Sopot, local authorities of other towns, cities and communes took to the idea of a participatory budget $[12,13]$. The mechanism and procedure applied in Sopot are still seen as a perfect model, but each territorial government unit is trying to create its own unique participatory budget procedure (Table 1).

The paper reviews recent amendments to relevant legislation, presents legal basis for the implementation of participatory budgets in the communes of Jaworze, Kęty, Cieszyn and BielskoBiała, and considers the consequences resulting from the implementation. We compare individual constituents of procedures used in the examined communes and hypothesise that, regardless of the size of the commune, the participatory budgets implementation is always burdened with similar problems.

\section{Foundations of Functioning of Participatory Budgets on the Example of Selected Communes}

Recently, the role of participatory budgets in encouraging citizens to take an active part in the process of management of their commune has grown considerably $[15,16]$. The literature on the topic defines the notion of a participatory budget in a number of ways. It is described as a process of taking decisions, during which members of local communities may discuss and negotiate the channels of public resource distribution [17]. It is de- 
fined as a process through which local residents verbalise their demands (identify, discuss and prioritise), influencing the structure of budget expenditures [18]. It is a form of influence of residents of a local government unit on the distribution and spending of available public funds. Moreover, it is a decision-making process under which residents co-create the budget of a given city, co-deciding on the distribution of a specific pool of public funds [19]. The participatory budget can also be understood as a process, during which the inhabitants of a given territorial unit directly decide or co-decide on the allocation of all or part of the available public funds [20].

The literature sources frequently mention the following stages of the participatory budget procedure: preparation of the process ('stage zero'), development of the procedure rules, the education and information campaign, the development phase, the proposal submission phase, the verification phase, the discussion phase, the selection phase, the supervision of implementation phase, and final evaluation of the process [21,22].

B. Martela proposed a slightly different approach to the procedure (which is also referred to as a scheme), stating that the first stage (the so called 'stage zero') is the development of rules and approval of the scheme of the procedure. In the next stage, members of local communities are invited to submit proposals. Then, the proposals are evaluated with respect to their feasibility and eligible proposals, which can be put to vote, are shortlisted. The next stage is the process of selecting projects, which are going to be funded and implemented. The projects are then incorporated into the budget of the local government unit. The final stage is the implementation of the chosen initiatives. The participatory budget procedure involves additional activities, such as promotion and information campaigns, and ends with the evaluation of the process, which includes summing-up the whole edition and formulating recommendations for future editions [23].

Local government units often use a multi-stage evaluation system of applications: initial verification in terms of formal and content-related verification. Formal verification is performed by a designated unit of the municipal office (usually organisational) or a designated person (e.g. participatory budget coordinator in the case of Pszczyna commune). It consists in checking the correctness of the project proposal submission and completing the attachments as well as assessing the compliance of the project with the assumptions of the participatory budget (e.g. project value, place of its implementation). Alternatively, the substan- tive verification is performed by the organisational units of the municipal office or municipal organisational units (Bielsko-Biała, Cieszyn, Kęty communes). Verification depends on estimated project costs and the feasibility of the project, among other things. Projects with a positive substantive assessment are placed on the list of projects for voting (Kęty commune), or they are verified by the team for participatory budget (office employees, local government councillors, representatives of auxiliary units, social organisations, etc.), which finally approves this list (Bielsko-Biała and Cieszyn communes). In the case of small local government units, it may happen that the complete verification of the proposal and the decision on its inclusion in the list of projects for voting is made by the commune head (Jaworze commune). Only in this way, the selected projects are subject to voting, after which the inhabitants of local government units vote for the projects to be implemented. The participatory budget diagram created by B. Martel, does not impose detailed rules for the functioning of the participatory budget, but only indicates the direction of subsequent activities aimed at the implementation of the entire project. Therefore, it can be considered a universal solution. Only the detailed description of the conditions and procedures for conducting individual stages of the participatory budget may differ depending on the solutions adopted by authorities of a given local government unit.

We use the above scheme to discuss legal foundations for the participatory budgets implementation and review the operating procedures adopted in Jaworze, Kęty, Cieszyn and Bielsko-Biała communes. We selected these particular local government units as each of them represents a different type of a commune: Jaworze is a rural commune, Cieszyn is a municipality, Kęty is a rural-urban commune, and Bielsko-Biała is a city with poviat rights. Such juxtaposition of local government units helps confirm the thesis of the universality of the participatory budget, which may be implemented in any commune regardless of its kind and size.

As indicated before, 'stage zero' includes, first of all, deciding about the implementation of a participatory budget, developing rules for its functioning and taking steps towards its execution, e.g. publication of relevant legal acts ${ }^{1}$ [24]. Due to

\footnotetext{
${ }^{1}$ The City Hall in Bielsko-Biała. Resolution of the President of Bielsko-Biała of 9 June 2015 on execution of tasks related to the Participatory Budget resulting from resolution no VII/87/2015 of the City Council of Bielsko-Biała of 28 April 2015 (2015). Bielsko-Biała; The Communal Office in Jaworze. Resolution no 13/2016 of the Voyt of the Jaworze Commune of 29 January
} 
the absence of top-down legal regulations for participatory budgets, local government units willing to implement them must determine the basis for their functioning themselves $[25,26]$.

The four examined communes decided to implement their participatory budgets in the public consultation mode, concerning important matters for the commune, pursuant to article $5 \mathrm{a}$ of the Act on Commune Self-Government ${ }^{1}$. The rules and mode of execution of the consultation are stated in the resolution of the local council. In Jaworze, Cieszyn and Bielsko-Biała, such a provision was published in resolutions introducing the participatory budget. In Kęty, the foundation for the participatory budget implementation was laid by a resolution of the Mayor. Apart from the main legal acts introducing the participatory budget implementation (the resolution of local authorities), all four examined local government units passed additional legislation specifically dedicated to consecutive stages of implementation (e.g. voting regulations, schedules for consecutive stages, etc.).

In Kęty, Cieszyn and Bielsko-Biała communes, the participatory budgets for a given budget year were introduced well before the year began. It meant that the projects that were selected for implementation by voting could be included in the budget resolution for a given year well before the resolution was enacted by the local council. Quite a different approach was adopted in Jaworze, where a civic budget was created in the first half of the budget year, meaning that resources for this purpose were secured in the communal budget as a special reserve.

One of the main elements of the process of planning a participatory budget is the decision about the amount of commitment allocated to this purpose. The conducted analysis showed a significant discrepancy between the number of residents in the examined communes and the amount directed to a participatory budget. In the commune of Kęty, which has a population of ap-

2016 on detailed procedure and timetable of the participatory budget in the Jaworze Commune in 2016 (2016). Jaworze; The Communal Office in Kęty. Resolution no 138/2015/B of the Mayor of the Kęty Commune of 22 June 2015 on the participatory budget in 2016 (2016). Kęty; The Town Hall of Cieszyn. Resolution no 0050.563.2015 of the Mayor of the Town of Cieszyn of 15 July 2015 amending resolution no 0050.541.2015 of the Mayor of the Town of Cieszyn of 2 July 2015 on the timetable for participatory budget for 2016 and appointment of the Team (2015). Cieszyn.

${ }^{1}$ Act of 8 March 1990 on Commune Self-Government, Journal of laws of 2017 item 1875. Retrieved from: http://prawo.sejm. gov.pl/isap.nsf/DocDetails.xsp?id=WDU19900160095 (Date of access: 22.10.2019). proximately 35 thousand people, as much as 1.03 million was secured for participatory budgets. Simultaneously, Cieszyn, where the population is around 36 thousand, received only 300 thousand PLN. These sums amounted to $1.07 \%$ of the whole budget of Kęty and $0.22 \%$ of the budget of Cieszyn and $6.02 \%$ and $1.12 \%$, respectively, of all investment expenditures in these communes. Despite the fact that the communes of Kęty and Cieszyn have similar populations, in Kęty whose budget is about 30 \% smaller compared to Cieszyn, the financial envelope for participatory budget was several times thicker than in Cieszyn. In the commune of Jaworze, whose annual budget in 2014 was about 30 million PLN, only 100 thousand PLN was allocated for the participatory budget in 2016, which constituted $0.90 \%$ of the whole budget for investment. When it comes to Bielsko-Biała, the sum delegated to the participatory budget amounted to 3.75 million PLN (37.5 times more than in Jaworze), which was $3.82 \%$ of the total investment budget (about 4.2 times more than in Jaworze ${ }^{2}$ ).

The data presented in Table 2 do not show any correlations, which would facilitate the decision of how much money to allocate for the implementation of participatory budgets. In the examined communes, the amounts allocated for civic budgets were not dependent on the population of a given commune, its total budget and total investment sums for a given year. Therefore, the decision of how much to spend on a participatory budget cannot be made in accordance with any pattern because such a pattern does not exist. The most important factor to consider here is how much money a given commune can really put for this purpose.

The next step in 'stage zero' was to decide whether the resources of the civic budget should be divided into smaller portions distributed among different areas of the commune. Additionally, it should be decided whether to set an upper limit for the projects submitted for implementation or not. The population in Jaworze is just 7 thousand people, meaning that it is difficult to distinguish individual estates or villages. Thus, the division was not made, and the total sum allocated for the participatory budget was set at 100 thousand $\mathrm{PLN}^{3}$. The only limitation there

\footnotetext{
2 The Statistical Office in Katowice / Statystyczne Vademecum Samorządowca. Katowice.stat.gov.pl. (2015). Retrieved from: https://katowice.stat.gov.pl/statystyczne-vademecum-samorzadowca/. (Date of access: 09.03.2020).

${ }^{3}$ Ordinance No. 29/2015 of the Head of the Jaworze Commune of March 31, 2015 on detailing the procedure and schedule of the Civic Budget in Jaworze in 2015. Retrieved from https://
} 
Selected figures regarding the examined communes

\begin{tabular}{|l|c|c|c|c|}
\hline Commune & $\begin{array}{c}\text { Population in } \\
\mathbf{2 0 1 4}\end{array}$ & $\begin{array}{c}\text { Amounts allocated for } \\
\text { civic budgets in 2016 }\end{array}$ & $\begin{array}{c}\text { Annual budget in 2014 } \\
\text { (million PLN) }\end{array}$ & $\begin{array}{c}\text { Amounts spent on investment } \\
\text { in 2014 (million PLN) }\end{array}$ \\
\hline Jaworze & 7,000 & 100000,00 & 30,00 & 11,1 \\
\hline Kęty & 35,000 & 1030000,00 & 96,7 & 17,1 \\
\hline Cieszyn & 36,000 & 300000,00 & 138,6 & 26,9 \\
\hline Bielsko-Biała & 173,000 & 3750000,00 & 745,8 & 98,1 \\
\hline
\end{tabular}

Source: Own work.

was that the estimated value of one proposal may not exceed $50 \%$ of the total sum in the participatory budget. Moreover, in Cieszyn, the sub-division was not made and the worth of the submitted projects could not exceed 50 thousand PLN ${ }^{1}$. In Kęty, however, the total participatory budget was broken into auxiliary units according to the number of residents living in a given area. In Kęty, the proposals could not cost more than the subamount from the envelope allocated for each particular unit ${ }^{2}$. In Bielsko-Biała, the residents could submit projects for two different baskets: the citywide basket for which 1.5 million PLN was allocated, and the local basket (for projects dedicated to individual housing estates) where the allocated resources amounted to 2.25 million PLN ( 75 thousand PLN per one housing estate). In case of the citywide basket, the estimated value of submitted proposals could not exceed 0.5 million PLN, for local projects the value of one proposal could not exceed the sum allocated for each given estate $^{3}$. Citywide tasks include projects concerning more than one housing estate or the places which are not assigned to one housing estate, e.g. construction of a bicycle path running through several housing estates, a series of educational performances in various parts of the city, moderni-

jaworze.bip.info.pl/dokument.php?iddok=3196\&idmp=90\&r=r (Date of access: 13.02.2020).

${ }^{1}$ Resolution No.X / 70/15 of the Cieszyn City Council of 28 May 2015 on the rules and procedure for conducting public consultations with Cieszyn residents on part of the expenses from the budget of the city of Cieszyn for 2016. Retrieved from: file:///C:/Users/Lenovo/AppData/Local/Temp/X_70_15_ Bud\%C5 \%BCet\%20obywatelski.pdf (Date of access: 13.02.2020).

2 Regulation No. 138/2015 / B of the Mayor of Kęty Commune of 22 June 2015 on the civic budget for 2016, Retrieved from: https://budzetobywatelski.kety.pl/file/uploads/2015/20150622_0600_z_BO.pdf (Date of access: 13.02.2020).

${ }^{3}$ Resolution No. VII / 87/2015 of the City Council of BielskoBiała of April 28, 2015 on the rules and procedure for conducting public consultations with the residents of Bielsko-Biała on the budget of the city of Bielsko-Biała for 2016. Retrieved from: file://C:/Users/Lenovo/AppData/Local/Temp/VII_87_2015-1. pdf (Date of access: 13.02.2020). sation public pitch, etc. Alternatively, local tasks (local basket) are those that relate to the needs of residents of one housing estate, e.g. building a car park, equipping a housing estate playground, purchasing equipment for the local community, educational lectures for housing estate residents, etc. ${ }^{4}$

\section{New Polish Regulations on Participatory Budgets}

Until recently, local authorities determined the use of participatory budgets locally, as there were no relevant national regulations. A uniform definition of a participatory budget did not exist either. The situation was changed by the Act of 11 January 2018 Amending Certain Acts to Increase Participation of Citizens in the Process of Selecting, Operating and Controlling Some Public Bodies. One of the acts amended by the 2018 legislation was the Act of 8 March 1990 on Commune Self-Government, which included a clause that participatory budget is a special form of social consultations. Within participatory budgets, by popular vote the residents decide how a part of the communal budget should be spent. Such a clause may be considered the first definition of 'participatory budget' in Polish legislation. Moreover, the amended act stipulated that the participatory projects chosen for implementation must be included in the budget resolution of the commune. Thus, while working on the budget resolution draft, the local council cannot delete or drastically change the tasks to be executed within the participatory budget. It was also indicated that the resources spent within the participatory budget may be split into pools embracing the entirety of the commune or its part in the form auxiliary units or groups of auxiliary units. The new provisions authorise, by way of a resolution, local councils to determine the requirements that proposals, chosen for the implementation within participatory budgets, must meet. In particular, the resolution regulates:

\footnotetext{
${ }^{4}$ Information on the implementation of the winning tasks of the Civic Budget in 2016. Retrieved from: https://obywatelskibb. pl/2017/aktualnosci/20170328/61/informacja_dotyczaca_realizacji_zwycieskich_zadan_budzetu_obywatelskiego_w_ roku_2016.html (Date of access: 13.02.2020)
} 
1. formal requirements for the submitted proposals;

2. the required number of signatures of citizens supporting the proposal with a remark that the number cannot be higher than $0.1 \%$ of all residents inhabiting the area covered by the pool for the participatory budget;

3 . the rules for the evaluation of the submitted proposals regarding their legitimacy, technical feasibility, fulfilment of formal requirements and the procedures of appealing if the project was rejected;

4. the rules of voting, determination of results and their release to the general public, considering that the rules of voting must ensure equality and directness.

The aforementioned provisions also apply to poviats and voivodeships under the Act of 11 January 2018, which amended the Act on District (poviat) Self-Government of 5 June 1998 and the Act on Regional (Voivodship) Self-Government of the same date. These documents state that the competences of the local council of the commune were assigned, respectively, to the poviat council and the voivodeship assembly. Moreover, the regulations impose the obligation to implement the participatory budget procedure on communes, which are cities with poviat rights. In these local government units, the civic budget envelope must be at least $0.5 \%$ of expenditure of the poviats as recorded in the last submitted report on the implementation of the budget (the Act of 11 January 2018 Amending Certain Acts to Increase Participation of Citizens in the Process of Selecting, Operating and Controlling some Public Bodies, article 1.1b).

The introduction of the aforementioned provisions partly established the basis for the operation of participatory budgets in local government units, which voluntarily decide to make use of this instrument, and in poviats, which are obliged to do so. However, all central regulations refer only to 'stage zero'. The development and execution of the remaining phases is still in the hands of local authorities.

\section{Stages of the Participatory Budget on the Example of Selected Communities}

According to the procedure developed by B. Martela, the stages that come after 'stage zero' include submission of proposals by residents, verification of the feasibility of proposals, shortlisting of eligible initiatives, selection of projects to execute (by voting), their inclusion into the general budget of the LGU and, finally, implementation. In this section, we analyse and compare how four examined communes approached the consecutive implementation phases of the participatory budget.

The communes of Kęty and Cieszyn established that proposals for participatory budget may be submitted by any citizen without limitations regarding their age or place of residence. A similar solution was adopted in Jaworze where the authorities went even further and allowed local social organisations to submit proposals. In BielskoBiała, there was a limitation with respect to the age of applicants, meaning that only residents over 16 years of age could submit the projects. In case of local projects dedicated to one specific estate, only residents of this estate could submit proposals for verification. The communes of Kęty, Cieszyn and Bielsko-Biała required that each project proposal should be accompanied by a letter of support with signatures of residents in favour of these proposals. Simultaneously, such a solution serves as an early verification of social support for the submitted proposals. In Jaworze, a signed letter of support from residents was not required.

The next stage of the participatory budget procedure is the verification of the submitted proposals, during which they are evaluated with respect to their feasibility. The execution of this phase was similar in all examined communes. In Bielsko-Biała and Cieszyn communes, formal evaluation was performed by organisational units. Then, the projects were sent to substantive units, which verified their content (and in the case of Kęty commune, the content units also performed formal verification). The substantive verification of projects in all local government units included the verification of estimated costs, compliance of the project with applicable regulations, work, the possibility of project implementation within one budget year, and in the case of investment projects, whether the land for investment belongs to local government units. Thus, there are no restrictions regarding the type of projects submitted; they can be both investment and non-material ones (cultural events, additional equipment for budgetary units, etc). Investment projects must be implemented on land owned by local government units. In the participatory budget procedure developed in Bielsko-Biała, we discovered a clause referring to a situation in which a proposal is deemed impossible to execute. In this case, the verification body must provide a written explanation of the reasons for the rejection together with suggestions for improvements. When corrected, the proposals could be re-assessed. The authors of rejected proposals had the right to appeal to the President of the City of Bielsko-Biała 
Methods of voting for projects under the participatory budget in Cieszyn and Bielsko-Biała in 2016-2017

\begin{tabular}{|c|c|c|c|c|c|c|}
\hline & & & $\begin{array}{l}\text { Traditional } \\
\text { voting }\end{array}$ & $\begin{array}{c}\text { Electronic } \\
\text { voting }\end{array}$ & $\begin{array}{c}\text { Correspondence } \\
\text { voting }\end{array}$ & $\begin{array}{c}\text { Total number } \\
\text { of votes }\end{array}$ \\
\hline \multirow{2}{*}{$\begin{array}{l}\text { Cieszyn } \\
\text { commune }\end{array}$} & \multicolumn{2}{|r|}{2016} & 1604 & 2672 & 0 & 4276 \\
\hline & \multicolumn{2}{|r|}{2017} & 945 & 1461 & 0 & 2406 \\
\hline \multirow{4}{*}{$\begin{array}{l}\text { Bielsko-Biała } \\
\text { commune }\end{array}$} & \multirow{2}{*}{2016} & Local projects & 2938 & 3571 & Not applicable & 6509 \\
\hline & & City-wide projects & 7022 & 7328 & Not applicable & 14350 \\
\hline & \multirow{2}{*}{2017} & Local projects & 8135 & 4722 & Not applicable & 12857 \\
\hline & & City-wide projects & 18410 & 8190 & Not applicable & 26600 \\
\hline
\end{tabular}

Source: own work.

who had the final decision whether the project can be put to vote. The positively verified proposals were then sent to special commissions or teams (each commune used a different name for this body, e.g. in Kęty there was the Communal Team for Participatory Budget Consultations, while in Cieszyn it was called the Team for Participatory Budget). The commissions or teams decided which tasks and projects could be put to vote. The members of teams or commissions were employees of the Municipal/Communal Office appointed by the voyt/mayor/president; they often included representatives of the commune councillors, estate councils and social organisations (the communes of Kęty and Cieszyn), local entrepreneurs (Kęty) or authors of the proposals (Jaworze). In the case of the Jaworze commune, it was the voyt who conducted the content-based verification of proposals and decided which projects could be put to vote.

The next stage of the participatory budget procedure was the selection of projects for funding and execution. In Jaworze, the residents had to arrive at the building of the Communal Office to cast their ballots, but everywhere (including Jaworze) it was possible to vote online. Provisions allowing for electronic voting have been included in the regulations governing the functioning of the participatory budget in a given local government unit $^{1}$. In Cieszyn, the residents could also vote by

\footnotetext{
${ }^{1}$ Resolution No. V / 38/2015 of the Jaworze Commune Council of February 26, 2015 on the rules and procedure for conducting public consultations in relation to the implementation of the commune's tasks under the so-called Of the Civic Budget in Jaworze. Retrieved from http://dzienniki.slask. eu/WDU_S/2015/1106/akt.pdf (Date of access: 13.02.2020); Resolution No. X / 70/15 of the Cieszyn City Council of May 28, 2015 on the rules and procedure for conducting public consultations with Cieszyn residents on part of the expenses from the budget of the city of Cieszyn for 2016. Retrieved from: https:// bip.um.cieszyn.pl/uchwala/4210/uchwala-nr-x-70-15 (Date of access: 13.02.2020); Regulation No. 138/2015 / B of the Mayor of the Kęty Commune of June 22, 2015 on the civic budget for 2016. Retrieved from: http://www.2016.budzetobywatelski.kety. pl/zarzadzenie (Date of access: 13.02.2020); Resolution No. VII / 87/2015 on the principles and procedure for conducting public
}

post. Kęty and Bielsko-Biała put up external polling stations. After the vote, the teams/commissions for participatory budgets had prepared reports on the results of the voting (Table 3).

In the case of the Cieszyn commune, the inhabitants were most interested in electronic voting. This option was used by $62.5 \%$ of voters in 2016 and by $60.7 \%$ in 2017 . The traditional form (in the City Hall) was less popular among the inhabitants (37.5 \% and $39.3 \%$, respectively). However, none of the residents of Cieszyn voted by post in the analysed period. One of the reasons for voting electronically was the convenience of saving time. In the case of the Bielsko-Biała commune, in 2016, the inhabitants were more interested in voting electronically, both for local projects $(54.9 \%$ of voters) and citywide projects (51.1\%). However, in the next edition of the participatory budget (2017), traditional votes prevailed (36.7\% and $30.78 \%$, respectively). The result was due to the high availability of traditional polling stations, as each of the 30 housing estates had a designated voting place, and three more stations were located in the buildings of the City Hall. As can be seen in the above examples, despite the availability of electronic solutions that shorten the resident-commune distance, the final choice of the form of voting by residents was influenced by their individual preferences and habits (sometimes information competences, in the case of older people).

The final stage of the procedure was the execution and implementation of the winning projects. The projects chosen by vote had to be included in the budget resolution for a given year in all examined communes. The list of selected projects was transferred to the voyt/mayor/president as a recommendation the implementation in the budget year for which the participatory budget procedure was conducted. The decision on which pro-

consultations with the residents of Bielsko-Biała on the budget of the city of Bielsko-Biała for 2016. Retrieved from: https: // bip .um.bielsko.pl / a, 60498, Uchwala-nr-vii872015-on-theprinciples-and-mode-of-conducting-social-consultationswith-residents-.html (Date of access: 13.02.2020). 
jects would indeed be included in the budget resolution draft belonged to the voyt/mayor/president, whereas the decision on which projects would be funded and implemented was taken later by the local council whose task was to enact the draft.

The examined communes did not introduce any solutions, which would regulate the mode of informing the residents about the details of successful projects. Usually, the information was communicated through local media, social media and Internet portals. In Bielsko-Biała, the regulations introducing participatory budget included a clause regarding supervision of the implementation of participatory projects. Pursuant to this clause, the City Secretary was obliged to prepare a report on the state of progress within the participatory budget in a given year and publish it on the Participatory Budget website. Such a clause is a manifestation of the transparency of finances of local government units, which allows the residents to verify the execution of successful projects. Moreover, publication of such information is also beneficial from the marketing point of view.

B. Martela does not regard education and information campaigns as a separate stage of the participatory budget scheme, because informative actions are an integral part of each individual stage of the participatory budget procedure. The information that should be made public include the value of the participatory budget, the call for proposals, the dates and rules of voting, the list of successful projects, etc. How this information should be communicated is not specified; the most important thing is that the information should reach the highest possible number of recipients. Another supplementary activity mentioned by B. Martela is the evaluation of the process, which includes summing-up of the current edition of participatory budget and formulation of recommendations for future editions. This activity cannot be considered as a separate stage either because any changes made in subsequent editions of the participatory budget should be the consequence of supervision over past editions and an attempt to eliminate previously made mistakes.

\section{Problems Related to Determination of the Rules of Operation of Participatory Budgets}

The analysis of the rules of operation of participatory budgets shows that the examined communes applied different regulations for the same stages of the participatory procedure. Some solutions used in the communes could cause controversies and have a negative reception.

The problems related to 'stage zero' have largely been eliminated by increasing the participation of citizens in the process of selecting and supervising some public bodies (the Act of 11 January 2018) ${ }^{1}$. For example, in the commune of Pszczyna, the participatory budget for 2016 was introduced by a resolution. The resolution published in the Official Journal of the Silesian Voivodeship entered into force on the 14th day after its publication. The regulatory taking of the Silesian Voivod of 30 September $2015^{2}$ repealed this resolution because it is not an act of local law. The authorities of Pszczyna commune appealed this decision to the District Administrative Court, which accepted the complaint. It was pointed out that the participatory budget must be introduced by a resolution of the local council, however it was not made clear whether the resolution should constitute an act of local law which shall be published in the Official Journal of the Voivodeship or not.

Another issue may be the age limitation for residents involved in participatory budgets. Relevant regulations treat participatory budgets as a specific form of social consultations. The rules and mode of consultations with residents are specified in the resolution of the local council. However, article $5 \mathrm{a}$ of the Act on Commune SelfGovernment ${ }^{3}$ stipulates that all residents of the commune are entitled to take part in social consultations. Therefore, imposing age limitation on entities entitled to take part in social consultations may be inconsistent with the provision cited above. The Act on Commune Self-Government gives the communes the 'mandate' to formulate the rules and mode of social consultations, but it does not establish legislation to determine which entities are entitled to take part in social consultations. Such an interpretation was presented in the regulatory taking of the Silesian Voivod ${ }^{4}$ with respect to the participatory budget of the Jaworze commune in 2015. The participatory budget resolution of the local council in Jaworze was repealed on the grounds that if the commune decides to

\footnotetext{
${ }^{1}$ Act of 11 January 2018 amending certain acts to Increase Participation of Citizens in the Process of Selecting, Operating and Controlling Some Public Bodies, Journal of Laws of 2018, item 130.

2 Supervisory Resolution No NPII.4131.1.352.2015 Ślaskie Voivodship. g.ekspert.infor.pl. (2015). Retrieved from http://g. ekspert.infor.pl/p/_dane/akty_pdf/U85/2015/60/2130.pdf. (Date of access: 12 01.2020)

${ }^{3}$ Act of 8 March 1990 on Commune Self-Government, Journal of laws of 2017 item 1875. Retrieved from: http://prawo.sejm. gov.pl/isap.nsf/DocDetails.xsp?id=WDU19900160095 (Date of access: 22.10.2019).

4 Supervisory Resolution No NPII.4131.1.127.2015 Ślaskie Voivodship. g.ekspert.infor.pl. (2015). Retrieved from: http://g. ekspert.infor.pl/p/_dane/akty_pdf/U85/2015/60/2130.pdf. (Date of access: 12 01.2020)
} 
implement participatory budget according to article $5 \mathrm{a}$ of the Act on Commune Self-Government and there are no other detailed provisions, all residents of the commune are entitled to take part in the participatory budget and there are no age limits in this respect. Although Jaworze appealed the regulatory taking of the Silesian Voivod and the District Administrative Court accepted the complaint, the whole situation is an example of problems related to the absence of detailed regulations for participatory budgets.

The next issue, which is partly resolved by new amendments to the legislation, is the time frame of execution of the participatory budget procedure. The legislation only regulates the issue of including the projects selected for implementation in the budget resolution draft but does not specify how long particular phases of the participatory budget should last. The only imposed obligation stipulates that the participatory budget must be introduced in the year preceding the budget year in which the projects will be implemented. The exception is Jaworze, where the participatory budget procedure is introduced in the first half of the budget year and the resources for this purpose are secured as a special reserve. This concept precludes the qualification of expenditures devoted to the implementation of selected projects in accordance with budget classification at the stage of budget planning and their inclusion in the budget resolution draft. Moreover, the solution adopted in Jaworze violates article 222 section 2 of the Act on Public Finance ${ }^{1}$. The Act states that communes may create special-purpose reserves whose value shall not exceed $5 \%$ of the expenditure of the budget of the local government unit on investments related to the execution of programmes co-financed by EU funds and on expenditure that a detailed breakdown of the budget classification may not be effected during the development of the commune's budget. Thus, special provisions may be created for expenditures upon which the commune authorities do not have an influence (unforeseen volumes or deadlines). The volume of expenditure connected with the participatory budget should be known at the time of the budget resolution planning.

As indicated before, the amount of resources allocated for participatory budgets should be determined by the financial capacity of each commune. New legal regulations only oblige cities with poviat rights to devote at least $0.5 \%$ of the total budget expenditure to this purpose. For other

${ }^{1}$ Act of 27 August 2009 on Public Finance, Journal of laws of 2017, item 2077. communes (rural, rural-urban and municipalities), the decision on the volume of resources allocated for the participatory budget should be made by the authorities of these communes. However, making the right decision may not be so easy.

Yet another issue is how to divide the participatory budget envelope. Without a clear division into particular estates/villages/districts, more densely populated areas will win every vote and smaller auxiliary units may never benefit from participatory resources. In smaller communes, where it is not possible to isolate individual estates or villages, a division of the participatory envelope is pointless. However, if the decision about dividing the resources has been made, it is necessary to consider whether each auxiliary unit (a district, village or estate) will get a fixed sum of money or the sum shall be determined depending on the number of residents in a given unit. This is important because various villages and districts are not proportional. When the envelope is distributed among particular auxiliary units, it may occur that some villages or estates submitted only one proposal or a number of proposals whose total value does not exceed the allocated sum for this estate. Then, it must be decided whether to organise a vote or not. Without the vote, the whole participatory budget procedure is much easier; on the other hand, this situation may have a negative impact on the popularity of the initiative because it misses the whole point of the participatory budget. Therefore, it is always important to consider the vote and set the threshold of a minimum turnout.

Another issue worth considering is the age of voters. The age limitation problem, which was already encountered in 'stage zero', may reappear in the next phase of the procedure during the submission of proposals. If underage persons are allowed to submit proposals, this situation may lead to inefficient public spending on projects with low social value. Life priorities change with age. Therefore, projects, especially investment ones, must be implemented to improve and facilitate the lives of all residents, both young and elderly people. One of the possible solutions for improving the effectiveness and accuracy of allocated funds is the separation of funds for the youth civic budget. Allowing social organisations to submit proposals may also turn out to be problematic. It should be emphasised that residents will more eagerly support and appreciate a proposal submitted by an organisation they recognise than an initiative proposed by an individual they have never met. In this way, social organisations have an advantage: having access to a wider pool of citizens, 
they may advertise their projects and encourage more residents to vote. It should also be noted that public organisations are more effective participants than individuals are. They have not only human, but also financial resources at their disposal. In this way, they are able to effectively influence a wide range of potential recipients (e.g. through social media, social campaigns, marketing campaigns, advertisements). This may lead to «forced» voting for projects that are more recognisable, though less suited to the needs of local residents.

A significant problem is also the rejection of projects, despite their social usefulness. The reason for this may be, among others, discretionary assessment of evaluation committees, lack of experience of applicants in submitting proposals, insufficient or unclear argumentation. It would be reasonable to introduce a two-stage substantive evaluation. At the first stage, the evaluation committee should draw attention to errors or indicate ambiguities in the project, expressing its position in the form of a recommendation. The applicant would be entitled to make corrections in line with the recommendations and submit the project for final evaluation or the second stage. In this way, not only would the number of good projects increase, but also the awareness and competencies of applicants would increase.

\section{Conclusion}

When it comes to the participatory budget procedure, it is necessary to allow citizens to correct any formal deficiencies in proposals. In this way, the number of socially valid proposals rejected on the grounds of insufficient knowledge concerning the required project documentation will be considerably reduced. It is especially important when the mistake in the proposal refers to the place of investment, which is not at the disposal of the commune.

Some problems may also appear at the voting stage. Here, the age limitation may be a challenge. Another thing is the voting method. While electronic vote does not give rise to any controversies, voting by paper ballots does. During electronic vote, a resident must register on an online voting service. The registration on the website requires providing data identifying a city resident, i. e., name and surname, email address, ID number, mobile phone number, home address. After registering on the website, the participant can start the voting process (at this point, we do not analyse the need to apply appropriate security measures and methods of verifying votes). However, for traditional voting and paper ballots, the key is the size of the commune and distance the residents must travel to cast a vote in their local office. The problem may be that polling stations are not always evenly placed; moreover, they are not open 24 hours a day, which limits the possibility of voting. In case of larger communes, it is advisable to organise polling stations to offer easy access for residents of all estates/villages/districts.

In addition, the issue of credibility needs to be addressed. The rules for determining the results must be transparent. Usually, the members of the 'commissions' or 'teams' responsible for participatory budgets count the votes. Such bodies must be transparent and conclusive with respect to the grounds of merit of the members to assure accurate voting results.

Until recently, projects selected by public vote were just a recommendation for implementation in a given budget year. The introduction of such a clause in the regulations introducing the participatory budget in a given commune did not guarantee that the project would really be implemented. The regulations in place did not oblige voyts/mayors/presidents to include the successful projects in the budget resolution draft for a given year. Even more than that, the inclusion of successful projects in the budget resolution draft was not a sufficient guarantee that the projects would be implemented since the local council must approve the draft.

Moreover, an approved budget resolution may be amended as the budget year progresses, meaning that some successful projects can be abandoned. The lack of guarantees that all successful projects would materialise could discourage some residents to take part in participatory budgets. Fortunately, this issue is now regulated by the act of 11 January 2018, which obliges communes to include all projects selected for implementation under participatory budgets in their budget resolutions. Additionally, the communes are not allowed to delete or amend these projects. Although the new regulations guarantee the implementation of participatory projects, this situation may be unfavourable for the communes as due to unforeseen expenses, there may be not enough money to pay for the implementation of civic projects [27].

During the development of rules for the operation of the participatory budget, it is important to balance which particular solution can assure the highest level of efficiency for this particular commune. The adopted solution should engage the widest possible audience and guarantee high voter turnout as the main assumption of the participatory budget is the involvement of big num- 
bers of residents in the process of deciding on local expenditure.

Although the idea of the participatory budget is still new in Poland, its popularity is constantly increasing, is it is considered a very effective instrument in building relationships between citizens and authorities [28]. However, changing procedures and uneven level of development of communes in Poland bring a whole set of organisational problems. Each commune has a different structure of revenues and expenditures and varying needs of residents. Implementation of an effi- cient participatory budget model may help to define those needs and lead to their satisfaction and further acceleration of the development of the commune.

The paper has shown that, up to the present moment, a satisfactory model for procedure of a participatory budget, which would optimise expenditure of local funds, has not been invented. Nevertheless, we described a direction for activities of local authorities to improve the efficiency of public spending and strengthen the bond between residents and their local authorities.

\section{References}

1. Sintomer, Y., Herzberg, C. \& Röcke, A. (2008). Participatory Budgetingin Europe: Potentials and Challenges. International Journal of Urban and Regional Research, 32(1), 164-178. DOI: https://doi.org/10.1111/j.1468-2427.2008.00777.x

2. Gawłowski, R. \& Popławski, M. (2019). Regional Civic Budgets - Copying, Inspiration or a New Structure? Samorząd Terytorialny, 1(1-2), 128-139. (In Polish.)

3. Glejt, P. \& Uziębło, P. (2018). Kilka uwag o „nowych” instrumentach partycypacji mieszkańców na poziomie samorzadowym [A few remarks about the "new» instruments of participation of residents at the local government level]. Wrocław: 393-403. Retrieved from: https://repozytorium.uni.wroc.pl/Content/89851/30_P_Glejt_P_Uzieblo_Kilka_ uwag_o_nowych_instrumentach_partycypacji_mieszkancow.pdf (Date of access: 09.03.2020) (In Polish)

4. Sorychta-Wojsczyk, B. (2015). Conditions of use of civic budget in public administration in Poland. Zeszyty Naukowe Politechniki Ślaskiej. Seria Organizacja i Zarzadzania [Scientific Papers of Silesian University of Technology - Organization and Management Series], 78, 421-430. (In Polish)

5. Drobiazgiewicz, J. (2019). The importance of a participatory budget in sustainable city management. Zeszyty Naukowe Akademii Morskiej w Szczecinie [Scientific Journals of the Maritime University of Szczecin], 59(131), 146-153.

6. Brun-Martos, M. I, \& Lapsley, I. (2017). Democracy, governmentality and transparency: participatory budgeting in action. Public Management Review, 19(7), 1006-1021.

7. Wiśniewska, M. \& Stawasz, D. (2016). Innovative methods of management in public sector. In: Managing Innovation and Diversity In Knowledge Society Through Turbulent Time: Proceedings Of The Makelearn And TIIM Joint International Conference 2016 (pp. 1047-1055). Toknowpress.

8. Rachwał, M. (2013). Participatory budgeting as a new form of co-decision in local financing. Przegląd Politologiczny [Political Science Review], 4, 173-185. (In Polish)

9. Dworakowska, M. (2014). Rola i znaczenie budżetu partycypacyjnego w rozwoju społeczeństwa obywatelskiego [The role and importance of participatory budget in the development of civil society]. In: J. Osiński, J. Popławska (Eds.), Oblicza społeczeństwa obywatelskiego - państwo, gospodarka, świat [Faces of the civil society - the state, economy, world]. Warszawa: Szkoła Główna Handlowa w Warszawie. (In Polish)

10. Williams, E., St. Denny, E. \& Bristow, D. (2017). Participatory Budgeting: An Evidence Review. Public Policy Institute for Wales, 28.

11. Tsobanoglou, G. \& Harms, H. (2018). Citizen's Participation and the Crisis of Representation in Europe. Models of Citizen Participation and the Quest for Local Democracy. Journal of Regional \& Socio-Economic Issues, 8(2), 47-59.

12. Pytlik, B. (2017). Participatory budget in Poland. Evolution and dilemmas. Studia z Polityki Publicznej [Public Policy Studies], 13(1), 103-122.

13. Kębłowski, W. \& Van Criekingen, M. (2014). Participatory Budgeting Polish-style. What kind of policy practice has travelled to Sopot, Poland? In: N. Dias (Ed.), Hope for Democracy. 25 years of participatory budget worldwide (pp. 369-377). São Brás De Alportel: In Loco Association.

14. Krenjova, J. \& Raudla, R. (2013). Participatory Budgeting at the Local Level: Challenges and Opportunities for New Democracies. Halduskultuur - Administrative Culturei, 14(1), 18-46.

15. Kocot, G. (2014). Budżet partycypacyjny w Polsce [Participatory budget in Poland]. In: J. Osiński, J. Popławska (Eds.), Oblicza społeczeństwa obywatelskiego — państwo, gospodarka, świat [Faces of the civil society - the state, economy, world]. Warszawa: Szkoła Główna Handlowa w Warszawie. (In Polish)

16. Wojciechowski, E. (2016). Problem budżetu obywatelskiego [The problem of the civic budget]. In: R. P. Krawczyk, A. Borowicz (Eds.), Aktualne problemy samorzadu terytorialnego po 25 latach jego istnienia [Current problems of local government after 25 years of its existence]. Łódź: Wydawnictwo Uniwersytetu Łódzkiego. (In Polish)

17. Wampler, B. (2007). A Guide to Participatory Budgeting. In: A. Shah (Ed.), Participatory budgeting (pp. 21-54). Washington: The World Bank. 
18. Chohan, U. W. (2016). The 'citizen budgets' of Africa make governments more transparent. The Conversation. Retrieved from: https://theconversation.com/the-citizen-budgets-of-africa-make-governments-more-transparent-58275 (Date of access: 09.03.2020)

19. Kłębowski, W. (2013). Budżet partycypacyjny. Krótka instrukcja obsługi [A concise guide to participatory budgeting in Poland]. Warszawa: Instytut Obywatelski, 41. (In Polish)

20. 72 Frequently Asked Questions about Participatory Budgeting. (2004). UN HABITAT, Urban Governance Toolkit Series, 86 .

21. Kraszewski, D., Skrzypiec, R. \& Wójkowski, G. (2015). Monitoring realizacji budżetu obywatelskiego. Raport $z$ pilotażowego etapu badania w 6 gminach województwa ślaskiego [Monitoring of the implementation of the civic budget. Report on the pilot stage of the study in 6 communes of the Sląskie Voivodeship]. Katowice: Stowarzyszenie Aktywności Obywatelskiej Bona Fides. (In Polish)

22. Bluj, A. \& Stokłuska, E. (2015). Budżet partycypacyjny (obywatelski) krok po kroku. Poradnik dla praktyków [Participatory (civic) budget step by step. A guide for practitioners]. Warszawa: Fundacja Pracownia Badań i Innowacji Społecznych „Stocznia”. (In Polish)

23. Martela, B. (2013). Participatory Budget in Poland - Implementation and Perspectives. Władza Sądzenia [Power of judgment], 2, 22-33. (In Polish)

24. Serzysko, E. (2015). Standardy Procesów Budżetu Partycypacyjnego W Polsce [Standards for Participatory Budget Processes in Poland]. Warszawa: Fundacja Pracownia Badań i Innowacji Społecznych «Stocznia.» (In Polish)

25. Wójcik, M. (2014). Village Fund in the Light of New Regulations. Prawo Budżetowe Państwa i Samorzadu [State and Local Government Budget Law], 2(4), 103-114. (In Polish)

26. Nowak, T. (2017). Dilemmas of Participatory Budgeting From The Perspective of The Polish Law and Experience. Revue Internationale Des Gouvernements Ouverts, 6(0), 59-70.

27. Thompson, D. (2008). Deliberative Democratic Theory and Empirical Political Science. Annual Review of Political Science, 11(1), 497-520. DOI: https://doi.org/10.1146/annurev.polisci.11.081306.070555.

28. Kurdyś-Kujawska, A., Kwiatkowski, G. \& Oklevik, O. (2019). Cities under participatory construction: Scale, dynamics, and constraints of participatory budgeting. International Journal of Environmental and Science Education, 14(5), 251-267.

\section{About the authors}

Jacek Binda - Professor, Dr. Hab. Inż., Department of Finance and Information Technologies, Vice Rector, BielskoBiała School of Finance and Law; https://orcid.org/0000-0002-2016-9933; Researcher ID: AAD-6102-2020 (5, Tańskiego St., Bielsko-Biała, 43-382, Poland; e-mail: jbinda@wsfip.edu.pl).

Sylwia Niedziela - Expert, Tax Administration Chamber in Katowice (25, Damrota St., Katowice, 40-022, Poland; e-mail: sylwia-niedziela@wp.pl).

\section{Информация об авторах}

Бинда Яцек - профессор, доктор технических наук, проректор, Департамент финансов и информационных технологий, Высшая Школа Финансов и Права в Бельско-Бяла; https://orcid.org/0000-0002-2016-9933; Researcher ID: AAD-6102-2020 (Польша, 43-382, г. Бельско-Бяла, ул. Таньского, 5; e-mail: jbinda@wsfip.edu.pl).

Недзеля Сильвия - эксперт, Палата налогового администрирования в Катовице (Польша, 40-022, г. Катовице, ул. Дамрота, 25; e-mail: sylwia-niedziela@wp.pl).

Дата поступления рукописи: 12.02.2020.

Прошла рецензирование: 25.08.2020.

Принято решение о публикации: 18.12.2020.

Received: 12 Feb 2020

Reviewed: 25 Aug 2020

Accepted: 18 Dec 2020 